\title{
Anti-Cataract and Plant Extracts-Based Natural Products: A Review
}

\author{
Feriyani ${ }^{1}$, Darmawi ${ }^{2,3}$, Rodiah Rahmawaty Lubis ${ }^{4}$, Ummu Balqis $^{5}$, Hady \\ Maulanza $^{6}$ \\ ${ }^{1}$ Graduate School of Mathematics and Applied Sciences, Universitas Syiah Kuala, Banda Aceh, Aceh, \\ Indonesia \\ ${ }^{2}$ Laboratory of Research, Faculty of Veterinary Medicine, Universitas Syiah Kuala, Banda Aceh, Aceh, \\ Indonesia \\ ${ }^{3}$ Laboratory of Microbiology, Faculty of Veterinary Medicine, Universitas Syiah Kuala, Banda Aceh, \\ Aceh, Indonesia \\ ${ }^{4}$ Department of Medical Study, Universitas Sumatera Utara, Medan \\ ${ }^{5}$ Laboratory of Pathology, Faculty of Veterinary Medicine, Universitas Syiah Kuala, Banda Aceh, Aceh, \\ Indonesia \\ ${ }^{6}$ Faculty of Medicines, Universitas Abulyatama, Aceh Besar, Aceh, Indonesia \\ *Corresponding author email: hdymaulanza_fk@abulyatama.ac.id
}

\begin{abstract}
Cataracts are of concern to the world as one of the diseases that cause blindness. Diabetes mellitus has a relationship with cataracts due to hyperglycemia through polyol pathways that are converted to sorbitol by the aldose reductase enzyme. Polyol pathway has implications for the pathogenesis of the formation of diabetic cataracts. The use of anticataract drugs using plants is considered as a solution for the formation of diabetic cataracts. Several studies on plant material have been developed for the treatment of diabetic cataracts that assess the performance potential of bioactive compounds through inhibition of the enzyme Aldose Reductase. Studies from various recent research results provide information that plants as natural products have the potential for a large solution of diabetes cataract prevention and treatment.
\end{abstract}

Keywords: Cataract, Hyperglycemia, Plants extract, Polyol Pathway, Aldose Reductase Inhibitor 


\section{INTRODUCTION}

Cataracts in Asia like China, India, Taiwan and Singapore averagely has prevalence of $14 \%$ to $49 \%$, where in the future the trend of cataract associated visual impairment is increasing [1]. Visual impairment is a serious problem in the whole world, in fact blindness, as one of visual impairments, has become global issue with the percentage of more than $1 \%$ of the total world population. World Health Organization (WHO) reported that the distribution of world population blindness has reached 45 people, especially in developing country such as Indonesia [2, 3]. A survey in 39 countries around the world reported that out of 285 people who have visual impairment, $50 \%$ of which is attributable to cataract affected by the age, diabetes complications and $13.7 \%$ blindness [4].

In some cases, free radicals trigger to induce lens opacification. The modification of protein by free radicals has been linked to severe oxidative stress, and Some studies shows that natural products from plants could be prevented protein insolubilization thereby delaying lens opacity [5].

Natural compounds consisting of antioxidant or anti-inflammatory secondary metabolites can serve as potential leads for anticataract agents. In this review, we tried to gather information form evidence plantbased natural products used for cataract treatment. This literature review is aimed at the evaluation of the potential natural products for anti-cataract.

\section{Cataract and Diabetes Mellitus}

Increasing trend of cataract sufferer follows the complications development of diabetes mellitus. Diabetes mellitus (DM) is an non-infectious disease with the characteristics of hyperglycemia [5]. It is associated with the organ pathophysiology caused by the dysregulation of metabolism of the sufferer, in which it can further cause various health complication [6] such as eyes impairment (retinopathy, cataract, etc.) as well as another organs impairment. Diabetes is one of the major causes of cataract development.

The increase of blood sugar concentration in diabetes is a significant cause of the diabetes complications that is cataract, where during hyperglycemia, glucose is converted through polyol pathway into sorbitol by aldose reductase enzyme, then into fructose with the sorbitol dehydrogenase acts as the catalyst [7]. Since polyol pathway has pathogenesis implication against diabetic cataract, it is suggested to do a prevention by inhibiting the enzymatic activities [8-10].

Aldose reductase (AR) is the main enzyme and the regulator in polyol pathway, where it catalyzes the formation of sorbitol by reducing the glucose aldehyde formation through NADPH conversion into $\mathrm{NADP}+$ simultaneously [11]. Consequently, tissue oxidative stress experiences an increase due to the depletion of NADPH activating the polyol pathway. In hyperglycemic condition of polyol pathway, there would be a different glucose metabolism compared to the normal condition. This difference allows the sorbitol-induced osmotic stress damaging the lens fibril and causing cataract, where the it is also possible to generate the oxidative stress causing other diabetic complications [12].

Glucose toxicity has a significant contribution against the development of eye complications of diabetes sufferers [13]. By focusing on aldose reductase inhibition, the diabetic complications can be reduced. Studies on aldose reductase inhibitor molecules through plant sourced synthesis is carried on in various laboratory experiment, even though a lot of improvement is needed, especially in safety and effectiveness of the synthesized product aspects [14, 15]. Many animal tests such as on mice, goat and rabbit, have been conducted to develop a safe and effective aldose reductase inhibitor, where its availability can meet the current market demand.

\section{Diabetic Cataract Treatment}

Until recently, surgery is the only treatment to remove cataract [16]. This adds more extraordinary socio-economic burden, especially in rural areas, where diabetes treatment and cataract surgery often neglected. Nevertheless, several revolutionary studies on non-surgery cataract treatment has been conducted to answer the world's blindness problem [17].

However, the effectiveness of this medication treatment does not have sufficient scientific proof, such as the experimental use of sorbitol concentration reducing drug on animals, where the it inhibits the glucose conversion into sorbitol, showed a positive result of diabetic cataract [18-20]. The application of anti-cataract drugs is considered as an alternative to reduce the effect of risking factors by controlling the 
blood glucose and consuming anti-oxidant rich nutrients [21].

\section{Anti-Cataract and Natural Plants}

The application of plants as traditional medicine has been practiced for more than thousands of years [22]. Development of scientific knowledge has motivated the studies to search the plant potentials as herbal medicine. It contains bioactive components such as flavonoid, this component represents phenolic compounds which can be widely found in various plants, where it also possesses useful health attribute for humans. That includes the anti-oxidant activity which protect the body from free radicals and other activities such as anti-bacteria, anti-microbe, antimutagenic and anti-inflammatory. The compounds ability to inhibit enzymatic activity has also been reported [23].

Traditional medicines are sourced from plants that are rich of bio-compounds and have the chemical uniqueness, thus more biomaterial-based medicines keep developing [24]. New bioactive compounds of flavonoids are the future research objective, to obtain it from various plants and evaluate its active structure. Exploring the correlation between the compound structure and its bioactivity, is a strategic approach to discover an ideal herbal medicine $[25,26]$.

\section{DISCUSSION}

The trend of plant-based biomaterials exploration pertaining anti-diabetic cataract has shown to be a potential source of Aldose Reductase Inhibitor (ARI). Some of the products act as pharmacology agents that inhibit $A R$, in which they have low toxicity due to their original sources from plants and fruits [27-30]. Some of known plant extract bioproducts that possess ARI activity are Ocimum santum, Withania somnifera, Curcuma longa and Azadirachta indica and Diabecon Indian herbal $[31,32]$. Recent studies within the last five years regarding the application of plant-based anti-cataract drugs can be observed on Table 1.

Besides, synthetic and semisynthetic product of ARI have also been developed with various types of medicine, but their effectiveness and side effects are still considered to have significant usage limitation. The medicine includes nonsteroidal anti-inflammatory drug such as Sulindac [33, 34], Aspirin [35, 36] or
Naproxen [37], which have been reported to give an effect of cataract delay on diabetic rats through weak AR inhibition. Despite those results, it can still be concluded that ARI is effective against oxidative stress, thus preventing the development diabetesinduced cataract.

Table 1. Plant extracts that have effectiveness and activities of AR inhibition [40-48]

\begin{tabular}{|c|c|c|c|}
\hline $\begin{array}{l}\mathrm{N} \\
\mathrm{O}\end{array}$ & Extract & Activity & $\begin{array}{l}\text { Animal } \\
\text { model }\end{array}$ \\
\hline 1 & $\begin{array}{l}\text { methanoli } \\
\mathrm{c} \text { extract } \\
\text { of } \text { Punica } \\
\text { granatum } \\
\text { leaves }\end{array}$ & $\begin{array}{l}\text { anti-diabetic } \\
\text { activity, AR } \\
\text { inhibitory activity } \\
\text { and anti-cataract } \\
\text { activity }\end{array}$ & $\begin{array}{l}\text { in vitro } \\
\text { in goat } \\
\text { lenses }\end{array}$ \\
\hline 2 & $\begin{array}{l}\text { Dendrobiu } \\
m \\
\text { aurantiacu } \\
m \quad \text { var. } \\
\text { denneanu } \\
\text { mis }\end{array}$ & $\begin{array}{l}\text { The effect of } \\
\text { Gigantol on the } \\
\text { development and } \\
\text { progression of } \\
\text { galactose induced } \\
\text { cataract, inhibit } \\
\text { enzymatic activity } \\
\text { of the AR and } \\
\text { iNOS }\end{array}$ & $\begin{array}{l}\text { in } \\
\text { vitro and } \\
\text { in vivo } \\
\text { in rats } \\
\text { lenses }\end{array}$ \\
\hline 3 & $\begin{array}{l}\text { Ethyl } \\
\text { acetate } \\
\text { fraction } \\
\text { of Saraca } \\
\text { indica (SI) }\end{array}$ & $\begin{array}{ll}\text { aldose } & \text { reductase } \\
\text { (AR) inhibitory } \\
\text { activity and anti- } \\
\text { cataract activity }\end{array}$ & $\begin{array}{lr}\text { in } & \text { vitro } \\
\text { in } & \text { rat } \\
\text { lens } & \end{array}$ \\
\hline 4 & $\begin{array}{l}\text { Zea } \\
\text { mays L. } \\
\text { (purple } \\
\text { waxy } \\
\text { corn) } \\
\text { seeds } \\
\text { extract }\end{array}$ & $\begin{array}{l}\text { aldose reductase } \\
\text { activity, oxidative } \\
\text { stress plays activity } \\
\text { (Superoxide } \\
\text { Dismutase, } \\
\text { Catalase, } \\
\text { Glutathione } \\
\text { Peroxidase) }\end{array}$ & $\begin{array}{l}\text { in vitro } \\
\text { in Male } \\
\text { Wistar } \\
\text { rats lens }\end{array}$ \\
\hline 5 & $\begin{array}{l}\text { Ethanolic } \\
\text { extract of } \\
\text { seed } \\
\text { kernel of } \\
\text { Caesalpini } \\
\text { a } \\
\text { bonducell } \\
\text { a (L.) } \\
\text { Fleming } \\
\end{array}$ & anticataract activity & $\begin{array}{l}\text { In vitro } \\
\text { in Goat } \\
\text { lens }\end{array}$ \\
\hline 6 & $\begin{array}{l}\text { methanol } \\
\text { extract } \\
\text { and water } \\
\text { extracts of } \\
\text { Coccinia }\end{array}$ & $\begin{array}{l}\text { antioxidant } \\
\text { activities and } \\
\text { aldose reductase } \\
\text { inhibitory activity }\end{array}$ & - \\
\hline
\end{tabular}




\begin{tabular}{|c|c|c|c|}
\hline & $\begin{array}{l}\text { grandis }(\mathrm{L} \\
.) \quad \text { fruits } \\
(\mathrm{CGFs})\end{array}$ & & \\
\hline 7 & $\begin{array}{l}\text { Flavonoid } \\
\text { s active } \\
\text { componen } \\
\text { ts of } \\
\text { Vernonia } \\
\text { cinereal } \\
\text { (lupeol) }\end{array}$ & $\begin{array}{l}\text { Antioxidants } \\
\text { activities }\end{array}$ & $\begin{array}{l}\text { In vivo } \\
\text { in } \\
\text { cataract } \\
\text { rats }\end{array}$ \\
\hline 8 & $\begin{array}{l}\text { Fruit, } \\
\text { Pericarp } \\
\text { and seeds } \\
\text { of } 80 \% \\
\text { ethanol } \\
\text { extract } \\
\text { from } \\
\text { Cornus } \\
\text { officinalis }\end{array}$ & $\begin{array}{l}\text { Inhibitory effect on } \\
\text { AGE formation, } \\
\text { Rat Lense Aldose } \\
\text { Reductase Activity, } \\
\text { Collagen -AGE } \\
\text { cross linking, } \\
\text { Xylose-induced } \\
\text { catactogenesis, and } \\
\text { breaking action on } \\
\text { AGE-protein cross } \\
\text { links }\end{array}$ & $\begin{array}{l}\text { In vitro } \\
\text { in lens } \\
\text { Rats }\end{array}$ \\
\hline 9 & $\begin{array}{l}\text { ethanol } \\
\text { extract } \\
\text { Chromola } \\
\text { ena } \\
\text { odorata } \\
\text { leaves }\end{array}$ & $\begin{array}{l}\text { Antidiabetic } \\
\text { activity with } \\
\text { prevention of } \\
\text { cataract formation }\end{array}$ & $\begin{array}{l}\text { Induced } \\
\text { diabetic } \\
\text { rats }\end{array}$ \\
\hline
\end{tabular}

Aldose reductase inhibitor (ARI) has different compound structures according to its sources such from plant extracts, animal tissue or small organ of an animal. To reduce the diabetic complication, the drug material should target the AR inhibition. Researches on such molecules have shown AR inhibition activity, obtained from plant extracts. The potential drug materials keep being develop for clinical evaluation, where there are persisting unsatisfying challenges pertaining the toxicity and effectiveness of the medicine $[14,15]$. A research on plant-based biomaterial has reported the effect of plant flavonoids to be effective against the cataract formation on diabetic rats. This positive result suggests that flavonoids in plants can delay the formation of diabetic cataract, the flavonoids include quercitrin and isoflavone genistein [49-51]. Several known plant extract-bioproducts that have AR inhibition activities include Ocimum sanctum, Withania somnifera, Curcuma longa, and Azadirachta indica or Diabecon Indian herbal [31, 32].
Several laboratory tests on animals such as mice, goat and rabbit have been massively conducted, where it is expected that the ARI activity can be safe, effective and available for market demand. The experimental researches are more intense by employing plant-based biomaterials, where they have shown a significant role in AR inhabitation, especially when these materials do not only delay the cataract formation but also the preventing the cataract itself.

Researches on rats have been carried out to evaluate the inhibition ability of the biomaterials against AR enzymatic activity, obtained from Punica granatum leaves [40], Dendrobium aurantiacum var. denneanumis [41], Saraca indica [42], Zea mays leaves [43] and Chromolaena odorata leaves [48]. Additionally, some fruits have been studied to have the similar ARI activity such as Cornus officinalis [47]. The activity of these plant extracts, do only possess the ability to inhibit AR, but also give other effects, which contribute to the in vitro and in vivo experimental results.

\section{CONCLUSION}

A review of those articles gives an information that plant as biomaterial resources, have a big potential in preventing and curing diabetic cataract. The researches offer a portrayal of plant-based biomaterials development as anti-cataract drugs, where other strong activities are also have been reported, such as anti-oxidant, AGE formation inhibition, anti-cataractogenesis and anti-diabetic.

\section{REFERENCES}

[1] Chua J, Koh JY, Tan AG, Zhao W, Lamoureux E, Mitchell P, et al. Ancestry, Socioeconomic Status, and Age-Related Cataract in Asians: The Singapore Epidemiology of Eye Diseases Study. Ophthalmology. 2015;122(11):2169-78.

[2] WHO. Action plan for the prevention of avoidable blindness and visual impairment, 2009-2013. 2010.

[3] Shanmugam P, Barigali A, Kadaskar J, Borgohain S, Mishra D, Ramanjulu R, et al. Effect of lanosterol on human cataract nucleus. Indian J Ophthalmol. 2015;63(12):888-90. 
[4] Pascolini D, Mariotti SP. Global estimates of visual impairment: 2010. Br J Ophthalmo. 2012;96(5):614-8.

[5] Tewari D, Samoilă O, Gocan D, Mocan A, Moldovan C, Devkota HP, et al. Medicinal Plants and Natural Products Used in Cataract Management. Front. Pharmacol. 2019;10(466).

[5] WHO. The world health report 2003: shaping the future: World Health Organization; 2003.

[6] Kasper DL, Fauci AS, Hauser SL, Longo DL, Jameson JL, Loscalzo J. Harrison's principles of internal medicine: McGraw Hill Education; 2015.

[7] Chung SS, Ho EC, Lam KS, Chung SK. Contribution of polyol pathway to diabetesinduced oxidative stress. JASN. 2003;14(suppl 3):S233-S6.

[8] Srivastava SK, Ramana KV, Bhatnagar A. Role of aldose reductase and oxidative damage in diabetes and the consequent potential for therapeutic options. Endocr Rev. 2005;26(3):380-92.

[9] Srivastava SK, Yadav UC, Reddy AB, Saxena A, Tammali R, Shoeb M, et al. Aldose reductase inhibition suppresses oxidative stress-induced inflammatory disorders. Chemico-biological interactions. 2011;191(1-3):330-8.

[10] Kumar P, Reddy G. Focus on molecules: aldose reductase. Experimental eye research. 2007;85(6):739-40.

[11] Yabe-Nishimura C. Aldose reductase in glucose toxicity: a potential target for the prevention of diabetic complications. Pharmacological reviews. 1998;50(1):21-33.

[12] Chatzopoulou M, Alexiou P, Kotsampasakou E, Demopoulos VJ. Novel aldose reductase inhibitors: a patent survey (2006--present). Expert opinion on therapeutic patents. 2012;22(11):1303-23.

[13] Kyselova Z, Stefek M, Bauer V. Pharmacological prevention of diabetic cataract. J Diabetes Complications. 2004;18(2):129-40.

[14] Dongare V, Kulkarni C, Kondawar M, Magdum C, Haldavnekar V, Arvindekar A. Inhibition of aldose reductase and anti-cataract action of trans-anethole isolated from Foeniculum vulgare Mill. fruits. Food chemistry. 2012;132(1):385-90.

[15] Kador PF. Overview of the current attempts toward the medical treatment of cataract. Ophthalmology. 1983;90(4):352-64.

[16] Pollreisz A, Schmidt-Erfurth U. Diabetic cataract-pathogenesis, epidemiology and treatment. J Ophthalmol . 2010;2010.

[17] Felici A, Mengato D, Falciani M, Bertelli E. Lanosterol Eye Drops in a Human Juvenile Nuclear Cataract. Arch Clin Med Case Rep. 2018;2(1):12-5.

[18] Kador PF, Webb TR, Bras D, Ketring K, Wyman M. Topical KINOSTAT ${ }^{\mathrm{TM}}$ ameliorates the clinical development and progression of cataracts in dogs with diabetes mellitus. Vet Ophthalmol. 2010;13(6):363-8.

[19] Kawakubo K, Mori A, Sakamoto K, Nakahara T, Ishii K. GP-1447, an inhibitor of aldose reductase, prevents the progression of diabetic cataract in rats. Biol Pharm Bull. 2012;35(6):866-72.

[20] Sankeshi V, Kumar PA, Naik RR, Sridhar G, Kumar MP, Gopal VH, et al. Inhibition of aldose reductase by Aegle marmelos and its protective role in diabetic cataract. J Ethnopharmacol. 2013;149(1):215-21.

[21] Sychev YV, Zepeda EM, Lam DL. Bilateral cataract formation via acute spontaneous fracture of the lens following treatment of hyperglycemic hyperosmolar syndrome. Am. J. Ophthalmol. Case Rep. 2017;7:66-9.

[22] Oyebode O KN, Chilton PJ, Lilford RJ. Use of traditional medicine in middle-income countries: a WHO-SAGE study. Health Policy and Planning 2016;31: 984-991.

[23] Russo D. Flavonoids and the StructureAntioxidant Activity Relationship. J Pharmacogn Nat Prod. 2018;4:e109.

[24] Dar RA SM, Rasool S, Qazi PH Natural product medicines: A literature update. The Journal of Phytopharmacology 2017;6: 340-342.

[25] Xu HX WM, Dong H, But PP, Foo LY, et al. . Inhibitory activity of flavonoids and tannins against HIV-1 protease. Biol Pharm Bull 23: 
1072-1076. Biol Pharm Bull 23: 1072-1076. 2000;23: 1072-1076.

[26] Mezrag A MN, Bouheroum M, Travaglino C, Russo D, et al. . Phytochemical and antioxidant activity studies on Ononis angustissima L. aerial parts: isolation of two new flavonoids. Nat Prod Res. 2017;31: 507514.

[27] Suryanarayana P, Kumar PA, Saraswat M, Petrash JM, Reddy GB. Inhibition of aldose reductase by tannoid principles of Emblica officinalis: implications for the prevention of sugar cataract. 2004.

[28] Saraswat M, Muthenna P, Suryanarayana P, Petrash JM, Reddy GB. Dietary sources of aldose reductase inhibitors: prospects for alleviating diabetic complications. Asia Pac J Clin Nutr. 2008;17(4):558-65.

[29] Muthenna P, Suryanarayana P, Gunda SK, Petrash JM, Reddy GB. Inhibition of aldose reductase by dietary antioxidant curcumin: mechanism of inhibition, specificity and significance. letters. 2009;583(22):3637-42.

[30] Akileshwari C, Muthenna P, Nastasijević B, Joksić G, Petrash JM, Reddy GB. Inhibition of aldose reductase by Gentiana lutea extracts. J Diabetes Res. 2012;2012.

[31] Moghaddam M, Kumar PA, Reddy GB, Ghole V. Effect of Diabecon on sugar-induced lens opacity in organ culture: mechanism of action. J Ethnopharmacol. 2005;97(2):397403.

[32] Halder N, Joshi S, Gupta S. Lens aldose reductase inhibiting potential of some indigenous plants. $\mathrm{J}$ Ethnopharmacol. 2003;86(1):113-6.

[33] Jacobson M, Sharma Y, Cotlier E, Hollander J. Diabetic complications in lens and nerve and their prevention by sulindac or sorbinil: two novel aldose reductase inhibitors. Invest. Ophthalmol. Vis. Sci. 1983;24(10):1426-9.

[34] Sharma Y, Vajpayee R, Bhatnagar R, Mohan M, Azad R, Kumar M, et al. Topical sulindac therapy in diabetic senile cataracts: cataract IV. Indian J Ophthalmol. 1989;37(3):127.
[35] Gupta S, Joshi S. Relationship between Aldose Reductase Inhibiting Activity and AntiCataract Action of Various Non-Steroidal Anti-Inflammatory Drugs1. Distribution of Cataracts in the Population and Influencing Factors. 21: Karger Publishers; 1991. p. 1516.

[36] Cotlier E. Aspirin effect on cataract formation in patients with rheumatoid arthritis alone or combined to diabetes. Int Ophthalmol. 1981;3(3):173-7.

[37] Gupta S, Joshi S. Naproxen: An Aldose Reductase Inhibitor and Potential AntiCataract Agent1. Distribution of Cataracts in the Population and Influencing Factors. 21: Karger Publishers; 1991. p. 170-8.

[38] Drel VR, Pacher P, Ali TK, Shin J, Julius U, ElRemessy $\mathrm{AB}$, et al. Aldose reductase inhibitor fidarestat counteracts diabetesassociated cataract formation, retinal oxidative-nitrosative stress, glial activation, and apoptosis. International journal of molecular medicine. 2008;21(6):667-76.

[39] Tang W, Martin KA, Hwa J. Aldose reductase, oxidative stress, and diabetic mellitus. Front. Pharmacol. 2012;3:87.

[40] Mestry SN, Juvekar AR. Aldose reductase inhibitory potential and anti-cataract activity of Punica granatum Linn. leaves against glucose-induced cataractogenesis in goat eye lens. Orient Pharm Exp Med. 2017;17(3):277-84.

[41] Fang H, Hu X, Wang M, Wan W, Yang Q, Sun $\mathrm{X}$, et al. Anti-osmotic and antioxidant activities of gigantol from Dendrobium aurantiacum var. denneanum against cataractogenesis in galactosemic rats. J Ethnopharmacol. 2015;172:238-46.

42] Somani G, Sathaye S. Bioactive fraction of Saraca indica prevents diabetes induced cataractogenesis: An aldose reductase inhibitory activity. Pharmacogn Mag. 2015;11(41):102.

43] Thiraphatthanavong $\mathrm{P}$, Wattanathorn $\mathrm{J}$, Muchimapura S, Thukham-Mee W, Wannanon P, Tong-Un T, et al. Preventive effect of Zea mays L.(purple waxy corn) on 
experimental diabetic cataract. Biomed Res Int. 2014;2014.

[44] Kurmi P, Konwar M, Das S. In-Vitro Anticataract Activity Of Ethanolic Extract Of Seed Kernel Of Caesalpinia Bonducella (L.) Fleming On Goat Lens. Pharma Science Monitor. 2015;6(1).

[45] Kondhare D, Lade H. Phytochemical profile, aldose reductase inhibitory, and antioxidant activities of Indian traditional medicinal Coccinia grandis (L.) fruit extract. 3 Biotech. 2017;7(6):378.

[46] Asha R, Devi VG, Abraham A. Lupeol, a pentacyclic triterpenoid isolated from Vernonia cinerea attenuate selenite induced cataract formation in Sprague Dawley rat pups. Chem. Biol. Interact. 2016;245:20-9.

[47] Kim JS. Seeds of Cornus officinalis and diabetic cataracts. Handbook of Nutrition, Diet and the Eye: Elsevier; 2014. p. 451-8.

[48] Onkaramurthy M, Veerapur V, Thippeswamy B, Reddy TM, Rayappa H, Badami S. Antidiabetic and anti-cataract effects of Chromolaena odorata Linn., in streptozotocin-induced diabetic rats. J Ethnopharmacol. 2013;145(1):363-72.

[49] Leuenberger P. Diabetic cataract and flavonoids. Klin Monbl Augenheilkd. 1978;172(4):4602.

[50] Huang R, Shi F, Lei T, Song Y, Hughes CL, Liu G. Effect of the isoflavone genistein against galactose-induced cataracts in rats. Exp. Biol. Med. 2007;232(1):118-25.

[51] Varma SD, Schocket SS, Richards R. Implications of aldose reductase in cataracts in human diabetes. Invest. Ophthalmol. Vis. Sci. 1979;18(3):237-41. 